\title{
The future of education and training in dental technology: designing a dental curriculum that facilitates teamwork across the oral health professions
}

IN BRIEF

- Improving teamworking between dentists and technicians is a matter for each and every practising dental clinician.

- An extensive literature search shows that interprofessional education is an emerging field within the oral health professions.

- Trends in teamworking are being seen increasingly in the dental literature.

\author{
J. Evans, ${ }^{1}$ A. Henderson ${ }^{2}$ and N. Johnson ${ }^{3}$
}

\section{VERIFIABLE CPD PAPER}

Teamwork is essential for the provision of contemporary, high quality oral health care. Teamwork skills need to be taught and learnt and therefore ought to be one of the core competencies in all dental education programmes: dentistry, oral health therapy, dental technology and dental assisting. Currently, lack of opportunities for collaborative learning and practice within educational establishments, and in the practising professions, hamper the development of effective teamwork. For students across oral health care, 'learning together' requires positive action for teamwork skills to be developed. Interprofessional curricula need to be formally developed, based on evidence from the wider education literature that demonstrates how to maximise the engagements needed for teamwork in practice. Rigorous study of interprofessional education within dentistry and oral health is in its infancy. Anecdotal evidence indicates that dental technology students who experience an interprofessional curriculum are better prepared for collaborative practice. Formalised interprofessional education is posited as an effective strategy to improve interactions among oral health professionals leading to improved patient care. This paper reviews the extant literature and describes the approach currently being trialled at Griffith University.

\section{INTRODUCTION}

The provision of successful intra-oral prosthetic appliances requires accurate communication of prescriptions between dentist and dental technician. ${ }^{1-6}$ Appropriate materials, effective techniques and careful design are essential for optimal aesthetics and function. The Australian Therapeutics Goods Act ${ }^{7}$ aligns with the Global Harmonisation Task Force ${ }^{8}$ and governs products used by dentists and dental technicians in Australia, as does the International Organization for Standardisation. ${ }^{9}$ The following materials (low risk class I - high risk class III) are used daily by dental technicians around the world:

1"BFET Senior Lecturer in Dental Technology, School of Dentistry and Oral Health, Griffith University, Australia: ${ }^{2}$ ALTC Associate Fellow, ALTC Discipline Scholar (Health) Professor Griffith Health, Griffith University and Nursing Director (Education), Metro South Health Service District, Queensland, Australia; ${ }^{3}$ Professor of Dental Research, Griffith Institute for Health and Medical Research, Foundation Dean (2005-2009), School of Dentistry and Oral Health, Griffith University, Australia *Correspondence to: Ms Jane Evans

Email: j.evans@griffith.edu.au

\section{Refereed Paper}

Accepted 1 February 2010

DOI: 10.1038/sj.bdj.2010.208

${ }^{\circledR}$ British Dental Journal 2010; 208: 227-230
'Examples of dental products: Class I - dental impression materials, artificial teeth, dental curing light; Class IIa - dental alloys, ceramics and polymers, orthodontic wire; Class IIb - permanent implants; Class III - absorbable implants. ${ }^{10}$

However, limited consultation between dentists and dental technicians regarding the choice and handling of these materials is commonplace, ${ }^{1,3,4,11-14}$ and written laboratory instructions are not always supplied by dentists. ${ }^{3,6,15,16}$ Effective implementation of safety requirements is a further aspect dependent on close cooperation. The potentially confusing plethora of materials currently available to dentists, combined with the reduction of teaching in prosthetic technology in many contemporary dental curricula, makes links between dentistry and dental technology education more imperative. ${ }^{13,17,18}$

Strengthening links between these related professions is possible through the deliberate creation of common curricular components. ${ }^{4,12,19}$ This view is supported by the General Dental Council of the United Kingdom, by the Association for Dental Education in Europe and by the American Dental Education Association. ${ }^{20-22}$ Griffith University, in Australia, has responded to this need by establishing interprofessional education (IPE) in the curricula of its suite of programmes in dental science, oral health therapy and dental technology. ${ }^{23,24}$

\section{Dental technology as a profession}

Professionalism is a term that has a variety of meanings. Interpretation is dependent on individual and group perceptions, attitudes and values, education, culture and experience. The Australian Concise Oxford Dictionary ${ }^{25}$ states professionalism to be: "qualities or typical features of a profession or of professionals especially in relation to competence and skill. ${ }^{25}$ This definition assumes that the norm - or 'typical features' - are congruent with accepted practice. Freidson ${ }^{26}$ emphasises that no matter what definition one embraces, professions are always evolving. Such is the case with dental technicians who play an increasingly active role in shaping dental treatment. Freidson's ${ }^{26}$ extensive analysis of professions suggested that in the 1970s they were predominantly a means of exerting power. Literature from the 1980s carried a prevailing theme that a profession has power over both what is practised and how it is practised..$^{27}$ This is particularly 
apposite to the provision of oral health services, where dentists have long held power and dominated decision making, with dental technicians in a subsidiary role. ${ }^{28}$ This is contrary to the ideals now proposed by the Australian National Health and Medical Research Council and others from Europe, the United Kingdom and the United States of America. ${ }^{17,19,29-35}$ More recently, professionalism is defined as not purely a 'job', but how one does the job. ${ }^{36}$ Dentists and dental technicians need open communication to ensure that they make decisions which are in the best interests of patients, coming as they have in the past from social and cultural groups with very different education, experiences, values and beliefs.

\section{Teamwork between dentist and dental technician}

Teamwork and inter-professional relationships have been identified among the attributes contributing to professionalism. ${ }^{37-41}$ These need to be fostered from the very beginning of professional education and training. There is growing support for interprofessional education across a wide range of health disciplines, but limited research related to the oral health professions. ${ }^{4,31,42,43}$ A study in the UK of one cohort of dental students, dental hygiene students and dental assistants recorded a positive attitude toward interprofessional education as a medium to improve communication and teamworking skills. ${ }^{31}$ This also showed that developing the 'professional identity' of students entering their particular programme was an important component for success. ${ }^{31}$ If dental technicians are to demonstrate truly professional practice, their curricula must provide opportunities to develop effective communication skills and appropriate teamwork. ${ }^{36}$ Curricula should involve all categories of oral health student in shared learning and understanding of complementary knowledge, collaborative development of skill-sets and joint participation in field work, fostering knowledge of individual roles and encouraging the teamwork, which Gallagher ${ }^{44,45}$ emphasises is so pertinent for the future dental workforce.

Dental technology must move beyond the traditional notion that its work is a 'trade' or an 'industry'. Dental technology is an art, but also a science that requires critical analysis of materials, designs and processes. If dental technicians themselves recognise their highly specialised and profound knowledge they are more likely to be respected as equal members of the dental team. Often the dentist values the dental technician's role more than the dental technician him/herself:

'The relationship between dentists and laboratories should be viewed as an interactive system. With full participation, better education, and wise management of information, this partnership can grow to the benefit of all concerned.' ${ }^{14}$

\section{The importance of communication and collaboration between dentist and dental technician}

Good communication is fundamental to effective team interactions ${ }^{46,47}$ and patient outcomes..$^{48}$ Meads and colleagues ${ }^{49}$ believe communication and trust are entwined. They state that behaviour needs to be congruent with communication style: a lack of openness can denote a lack of trust and undermine collaboration. ${ }^{49,50}$

This can also become an ethical issue, as discussed extensively by Rule and Veatch, ${ }^{39}$ when conflict and communication failures occur among clinicians - be they hygienist, dentist or specialist (eg an endodontist) involved in the shared care of a patient. This is equally true of communication between clinician and dental technician.

Dentistry is reliant on the artistic skills of the dental technologist to restore colour, form and function of the oral cavity and surrounding facial areas. At present there is frequently no, or poor, communication between dentists and dental technicians. ${ }^{111,12,51}$ Cooperation and respect need to be enhanced at all levels: in education, throughout professional practice and in the organisation of the professions. ${ }^{12,29}$ From the beginning, close links need to be established between the providers of education in both professions. ${ }^{12}$ If consultation and communication between dentist and technician is embedded in undergraduate studies it is more likely that graduates will continue this 'habit' into their professional lives. ${ }^{52}$ This has been recognised in the United Kingdom and is the underlying principle of the Griffith University curricula across the oral health professions. ${ }^{4}$

\section{OVERVIEW OF THE GRIFFITH UNIVERSITY CURRICULA}

Although other universities have attempted to bring shared learning experiences to pre-registration dentistry and dental technology students, to our knowledge no single institution in the English-speaking world has attempted to educate the whole spectrum of the oral health professions together. ${ }^{4,19}$ Griffith University in Queensland, Australia, has taken this step in establishing the first dental technology baccalaureate programme in Australia which is conducted concurrently and collaboratively with programmes in dentistry and in oral health therapy. ${ }^{23,53}$ We have embarked on a learning and teaching approach which aims to achieve professional activities that are inclusive, reflective and which meet the needs of consumers - our patients. ${ }^{54,55}$

The three year dental technology programme is structured to build theoretical knowledge that directly contributes to experiential and contextual learning in both laboratory and clinical environments across all the oral health professional groups. This is underpinned by the Three Foci of Interprofessional Education: ${ }^{52}$ individual preparation (skills development and knowledge), collaborative team work and improving services (Fig. 1)..$^{52}$

Consistent with the model proposed by Barr and colleagues ${ }^{52}$ all students enrolled in the first year of the Bachelor of Oral Health in Dental Science, Bachelor of Oral Health in Oral Health Therapy or the Bachelor of Oral Health in Dental Technology are provided with a solid foundation in health and human sciences, communication and one dental-specific course (Fig. 1). ${ }^{53}$ This first-year learning is undertaken in a multiprofessional environment. Multiprofessional education is defined as two or more professions learning in a shared/parallel environment, without expectation of interaction ${ }^{52}$ which is, however, encouraged through informal and social processes.

Second year features oral biology, microbiology, public health and community research, where multiprofessional education continues. The community research course initiates interprofessional education where all three professions learn with, from and about each other. ${ }^{56}$ In second year there are clinical and laboratory courses specific for each discipline but each of these incorporates team-based learning opportunities with focus on patient outcomes. The dental technology specific courses ${ }^{57}$ provide opportunities for 


\begin{tabular}{|c|c|c|c|c|c|c|c|}
\hline & \multicolumn{2}{|c|}{ 1st Year } & \multicolumn{2}{|c|}{ 2nd Year } & \multicolumn{2}{|c|}{ 3rd Year } & \\
\hline & Semester 1 & $>$ Semester 2 & $>$ Semester 3 & $>$ Semester 4 & $>$ Semester 5 & $>$ Semester 6 & \\
\hline $\begin{array}{l}\text { Individual } \\
\text { Preparation } \\
\text { stream }\end{array}$ & $\begin{array}{l}\text { Cell Biology, } \\
\text { Chemistry, } \\
\text { Biological Systems } \\
\text { \&t Regulation } \\
\text { Health Psychology }\end{array}$ & $\begin{array}{c}\text { Chemistry \& } \\
\text { Biological Systems, } \\
\text { Anatomy \& } \\
\text { Physiology, Dental } \\
\text { Materials }\end{array}$ & $\begin{array}{l}\text { Oral Biology, } \\
\text { Prosthetic } \\
\text { Technology }\end{array}$ & $\begin{array}{ll}\mid & \\
\mid & \text { Removable } \\
\mid & \text { Prosthetic } \\
\text { I } & \text { Technology } \\
\text { I } & \\
1 & \\
\end{array}$ & $\begin{array}{ll}\text { | } & \\
\text { | } & \text { Oral Pathology, } \\
\text { | } & \text { Research Fixed } \\
\text { | } & \text { Prosthodontics } \\
\text { I } & \\
\end{array}$ & 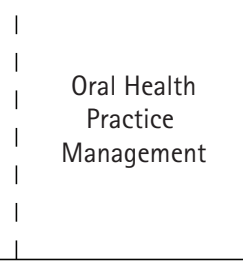 & $\begin{array}{l}\text { । } \\
\text { । } \\
\text { । } \\
\text { । }\end{array}$ \\
\hline $\begin{array}{l}\text { Collaborative } \\
\text { Team } \\
\text { Work Stream }\end{array}$ & & $\begin{array}{l}\text { Principles of } \\
\text { Community } \\
\text { Research }\end{array}$ & $\begin{array}{l}\text { Public Health, } \\
\text { Community } \\
\text { Research }\end{array}$ & $\begin{array}{l}\text { Removable } \\
\text { Prosthetic } \\
\text { Technology }\end{array}$ & $\begin{array}{c}\text { Fixed } \\
\text { Prosthetic } \\
\text { Technology, } \\
\text { Research }\end{array}$ & $\begin{array}{ll}\mid & \\
1 & \\
1 & \text { Contemporary } \\
\text { Prosthetic } \\
\text { I }\end{array}$ & $\begin{array}{l}1 \\
1 \\
1 \\
1 \\
1\end{array}$ \\
\hline $\begin{array}{l}\text { Patient Focus } \\
\text { Interprofessiona } \\
\text { Stream }\end{array}$ & & & $\begin{array}{l}\text { Removable } \\
\text { Prosthodontics }\end{array}$ & $\begin{array}{l}\text { Public Health } \\
\text { Community } \\
\text { Research, } \\
\text { Removable } \\
\text { Dentures } \\
\text { \& Orthodontics }\end{array}$ & $\begin{array}{l}\text { Community } \\
\text { Research, } \\
\text { Fixed } \\
\text { Prosthodontics }\end{array}$ & $\begin{array}{l}\text { Community } \\
\text { Research, } \\
\text { Team Based } \\
\text { Laboratory Practice }\end{array}$ & \\
\hline
\end{tabular}

Fig. 1 Streaming of interprofessional education within the Griffith University dental technology curriculum

interprofessional learning as dental technology students construct oral appliances for real patients being cared for by students in the undergraduate clinical streams and/or for graduate clinicians (dentists, prosthodontists and clinical dental technicians/prosthetists). For example a dental technology student may work closely with a fourth or fifth year dentistry student to design and construct a partial denture. S/ he has the opportunity to follow a patient case through the clinical stages as well as completing the laboratory work him/herself. Collaborative design involves discussing the most appropriate materials, detailed design of support, retention and path of insertion, shade selection, and care of the prosthesis - all in the light of the patient's expectations. Through this, both see the functions (roles) and requirements (responsibilities) of other team members. ${ }^{58}$

The third year of the programme includes a defined research project, practice management, oral pathology, oral medicine and further theoretical and practical prosthetic technology. In their final semester, dental technology students work with dentistry students to complete a range of prosthetic cases.

The community research course continues through all three years. ${ }^{57}$ Dental science, oral health therapy and dental technology students are allocated into groups from first year, second semester. They are assigned an academic tutor from one of the three professions and they work together within a community, conducting needs analysis, health promotion activities and some provision of oral health care. Their work is jointly assessed. ${ }^{57}$

\section{AN EXEMPLAR OF THE FINAL SEMESTER PRACTICAL}

Shade selection, a common procedure, is a method of recording and matching natural tooth colour to artificial teeth provided as part of dentures, crowns or bridges. The dentist and the technician attend the clinic together to design the prosthesis. The fourth or fifth year dentistry student prepares the mouth or tooth surfaces and the dental technician refines the design, inter alia ensuring it is appropriate to the material chosen to replace lost tooth structure. S/he refers to a range of shade guides provided by the manufacturer/supplier of the chosen material, in close consultation with the dental student and the patient. Decisions are recorded using drawings, photographs and symbols. The dental technology student then constructs the prosthesis, and attends clinical appointments for try-in, insertion and adjustment.

It is a valid hypothesis that the future dentist might acquire enhanced faith in, and respect for, the technician's knowledge, skills and professionalism in such a collaborative environment. This setting brings greater transparency to the patient care experience. In these situations patients also come to understand and to value the role of the technician, and are encouraged to provide direct feedback on laboratory procedures as well as clinical outcomes. The significant roles of the dental technician are not widely known by the public, so such interactions provide opportunities for enhanced professional recognition. ${ }^{52,59}$

From situations such as this, clinical and dental technology students are encouraged to reflect on their interactions, which are formally assessed in the curriculum through reflective journals. Anecdotal evidence to date suggests that both groups feel on a more equal footing, with better understanding of the 'role' each profession plays in patient care. When the dental technician can observe the fitted prosthesis and experience the patient's reaction, his/her opportunity for self reflection is enhanced, facilitating improved service to patients - an essential element of professionalism. ${ }^{52,59}$ 


\section{CONCLUSION}

With growing recognition, worldwide, of the benefits to be gained from better integration of the professional work practices of all members of the dental team, the Griffith model seeks to inculcate this from the very beginning of the educational process. The academic programme is designed to promote dialogue and engagement between all future providers of oral health care. ${ }^{60}$ By providing students from each of the oral health professional streams with the same basic science knowledge, and ensuring that dental technology and dental students have, for example, comparable knowledge of anatomy and of the principles of dental prosthetics, they can discuss patient cases using the same professional language. On completion of the programme, our dental technology students comment that they feel confident to interact with all relevant professional groups: they are also more likely to continue with further education. Feedback from employers of our first four cohorts of graduates is encouraging. This anecdotal feedback is being extended to rigorous evaluation by detailed qualitative and quantitative research, the results of which will be communicated in due course. In the meantime these positive views of the interprofessional education programmes at Griffith University encourage us to continue the current approach.

1. Afsharzand Z, Rashedi B, Petropoulos V. Communication between the dental laboratory technician and dentist: work authorisation for fixed partial dentures. J Prosthodont 2006; 15: 123-128.

2. Leith R, Lowry L, O'Sullivan M. Communication between dentists and laboratory technicians. $J$ Ir Dent Assoc 1999; 46: 5-10.

3. Lynch C D, Allen P F. Quality of communication between dental practitioners and dental technicians for fixed prosthodontics in Ireland. J Oral Rehabil 2005; 32: 901-905.

4. Reeson M G, Jepson N J A. 'Bridging the gap'. Should the training of dental technicians be linked with that of the dental undergraduate? Br Dent J 2005; 198: 642-645.

5. Davenport J C, Basker R M, Heath J R et al. Communication between the dentist and the dental technician. Br Dent J 2000; 189: 471-474.

6. Juszczyk A S, Clark R K F, Radford D R. UK dental laboratory technicians' views on the efficacy and teaching of clinical-laboratory communication. BrDent J 2009; 206: E21.

7. Therapeutic Goods Act 1989, Commonwealth of Australia. http://www.comlaw.gov.au/comlaw/ Legislation/ActCompilation 1.nsf/0/8257AD1CF62F0 DCACA25764900016705?0penDocument Cited 28 October 2009 Sess.

8. Global Harmonisation Task Force. Website Homepage. 1992 (cited August 2008). Available from: www.ghtf.org.

9. International Organization for Standardisation. Dental Materials. 2009 (cited October 2009). Available from: http://www.iso.org/iso/search.htm?qt=dental+materia Isctsort=relitype=simplectpublished=true.

10. Australian Government, Department of Health and Aging, Therapeutics Goods Administration. Regulatory Requirements for Dental Products, Information Document no.30. Canberra 2007 (cited August 2008). Available from: http://www.tga.gov. au/docs/html/dentalreg.htm.

11. Afsharzand Z, Rashedi B, Petropoulos V. Dentist communication with the dental laboratory for prosthodontic treatment using implants. $J$ Prosthodont 2006; 15: 202-207.

12. Barrett PA, Murphy W M. Dental technician education and training - a survey. Br Dent J 1999; 18: 85-88.

13. McGarry T J, Jacobsen T E. The professions of dentistry and dental laboratory technology: improving the Interface. J Am Dent Assoc 2004; 135: 220-226.

14. Warden $\mathrm{D}$. The dentist laboratory relationship: a system for success. J Am Coll Dent 2002; 69: 12-14.

15. Leith R, Lowry L, O'Sullivan M. Communication between dentists and laboratory technicians. J Ir Dent Assoc 2000; 46: 5-10.

16. Lynch C D, Allen P F. Quality of written prescriptions and master impressions for fixed and removable prosthodontics: a comparative study. Br Dent J 2005; 198: 17-20.

17. Challoner $\mathrm{R}$. The changing roles of the dentist and dental laboratory. J Am Coll Dent 2002; 69: 6-8.

18. McCord J F, Grant A A. Complete dentures: an introduction. Br Dent J 2000; 188: 373-374

19. Cannavina G, Wood D, Winstanley R B, Walsh T F. A retrospective study of shared learning on the BMedSci dental technology course at the University of Sheffield. Eur J Dent Educ 2000; 4: 160-164.

20. American Dental Education Association (ADEA)'s Commission on Change and Innovation in Denta Education. The Dental Education Environment. J Dent Educ 2006; 70: 1265-1270

21. Association for Dental Education in Europe, Plasschaert A J M, Holbrook W P et al. DentEd III Thematic Network Project, Profile and Competencies for the European Dentist. Netherlands 2004 (cited 9 November 2006). Available from: http://dental. medic.upjs.sk/Profile_and_Competences_for_the European Dentist english.pdf.

22. General Dental Council. Developing the dental team: curricula frameworks for registrable qualifications for professionals complementary to dentistry (PCDs). 1st ed. London: GDC, 2004

23. Cripps $A$, Johnson N W, Boocock $\mathrm{H}$ et al. (eds). A new suite of programmes in dentistry and oral health: challenges in interprofessionalism, internationalisation and innovation. Gold Coast, Australia: Australian International Education Conference, 2005.

24. Short L M, Evans J, Mackay J et al. Griffith University. In Tsang A K L (ed). Oral health therapy programs in Australia and New Zealand - its emergence and development 2010. Gold Coast: Knowledge Books \& Software (in press).

25. Moore B (ed). The Australian Concise Oxford Dictionary. 4th ed. Melbourne: Oxford University Press, 2004

26. Freidson E. Professionalism reborn: theory, prophecy and policy. Chicago: The University of Chicago Press, 1994.

27. Ozar D T. Three models of professionalism and professional obligation in dentistry. J Am Dent Assoc 1985; 110: 173-177.

28. Freidson E. Professional powers. Chicago: University of Chicago Press, 1986.

29. Christensen G J. A needed remarriage: dentistry and dental technology. J Am Dent Assoc 1995; 126: $116-117$

30. Field M J (ed). Dental education at the crossroads: challenges and change. Washington: Division of Health Care Services Institute of Medicine National Academy Press, 1995.

31. Morison S, Marley J, Stevenson M, Milner S. Preparing for the dental team: investigating the views of dental and dental care professional students. Eur J Dent Educ 2008; 12: 23-28.

32. National Health and Medical Research Council. The impact of change in oral health status on dental education workforce, practice and services in Australia. Canberra, 1993.

33. Association for Dental Education in Europe, Cowpe J, Plasschaert A et al. Profile and Competences For the Graduating European Dentist (Update 2009). (cited 6 November 2009.) Available from: http://www.adee.org/cms/uploads/adee/ ProfileCompetencesGraduatingEuropeanDentist1.pdf.
34. Oliver $\mathrm{R}$, Kersten $H$, Vinkka-Puhakka $\mathrm{H}$ et al. Curriculum structure: principles and strategy. Eur J Dent Educ 2008; 12: 74-84

35. Sanz M, Treasure E, van Dijk W et al. Profile of the dentist in the oral healthcare team in countries with developed economies. Eur J Dent Educ 2008; 12: 101-110.

36. Makely S. Professionalism in health care: a primer for career success. 2nd ed. New Jersey: Pearson Prentice Hall, 2005.

37. American Board of Internal Medicine. Project professionalism. Philadelphia, 2002 (cited 14 April 2006). Available from: www.abim.org.

38. Ozar D T, Sokol D J. Dental ethics at chairside: professional principles and practical application. Washington: Georgetown University Press, 2002.

39. Rule J T, Veatch R M. Ethical questions in dentistry. Illinois: Quintessence Books, 1993.

40. University of Western Ontario. Charter on Medical/ Dental Professionalism 2003. University of Western Ontario, 2003. (cited 17 January 2006.) Available from: www.schulich.uwo.ca/Administration/ Professionalism.pdf.

41. Van De Camp K, Vernooij-Dassen M, Grol R P, Botema B J. How to conceptualize professionalism: a qualitative study. Med Teach 2004; 26: 696-702.

42. Christensen G J. The dental laboratory dilemma in America. J Am Coll Dent 2002; 69: 9-11.

43. Eaton K A, de Vries J, Widstrom E et al. 'Schools Without Walls?' Development and challenges in dental outreach teaching - report of a recent symposium. Eur J Dent Educ 2006; 10: 186-191.

44. Gallagher J E, Wilson N H F. The future dental workforce? Br Dent J 2009; 206: 195-199.

45. Gallagher J L, Wright D A. General dental practitioners' knowledge of and attitudes towards the employment of dental therapists in general practice. Br Dent J 2003; 194: 37-41.

46. Miller C, Freeman M, Ross N. Interprofessional practice in health care and social care: challenging the shared learning agenda. London: Arnold, 2001.

47. Rudland J R, Mires G J. Characteristics of doctors and nurses as perceived by students entering medical school: implications for shared teaching. Med Educ 2005; 39: 448-455.

48. Duff R S, Hollingworth A B. Sickness and society. New York: Harper \&t Row, 1968.

49. Meads G, Ashcroft J, Barr H, Scott R, Wild A. UK Centre for the Advancement of Interprofessional Education (ed). The case for interprofessional collaboration. Oxford: Blackwell, 2005

50. Tyler S, Kossen C, Ryan C. Communication: a foundation course. 2nd ed. Sydney: Prentice Hall, 2002.

51. Hancock R (ed). Education and training of personnel auxiliary to dentistry. Norwich: Nuffield Foundation, 1993.

52. Barr H, Koppel I, Reeves S, Hammick M, Freeth D. Effective interprofessional education: argument assumption and evidence. Oxford: Blackwell Publishing, 2005.

53. School of Dentistry and Oral Health. Accreditation of a New Program: Bachelor of Oral Health in Denta Technology. Gold Coast: Griffith University, 2004.

54. School of Dentistry and Oral Health Team, Coleman $\mathrm{H}$, Evans J et al. Curriculum Half Day Workshop. Griffith University, 2004.

55. School of Dentistry and Oral Health. Planning Day Meeting, Integrating Curriculum. Griffith University, 2007.

56. Centre for the Advancement of Interprofessional Education. Defining IPE. United Kingdom 2002 (cited 17 February 2008). Available from: www. caipe.org.uk/about-us/defining-ipe/

57. School of Dentistry and Oral Health. Program Structure: Course Descriptions. Gold Coast 2009 (cited 10 November 2009). Available from: http:// www17.griffith.edu.au/cis/p_cat/require.asp?ProgC ode $=1260$ etType $=$ structure.

58. Mattheos N, Foster L, Oberholzer T. A novel team-based concept of treatment planning for training in the comprehensive care clinic. Helsinki: 35 th Congress of the Association for Dental Education in Europe, 2009.

59. Bronstein L R. Instrument development: index of interdisciplinary collaboration. Soc Work Res 2002: 26: $113-123$.

60. Nuffield Committee, T C Thomas (ed). An enquiry into dental education. London: Nuffield Foundation, 1980 